\title{
Assessment of Management Modules against Yellow Stem Borer in Paddy
}

\author{
S BHUSHAN* AND RAVI SHANKER
}

\begin{abstract}
Yellow stem borer (YSB) is one of the most serious and monophagous pest of paddy in India. Field experiments were carried out to assess the different management modules against the yellow stem borer in paddy during the Kharif season of 2019 and 2020. The results on efficacy of modules revealed that during both the years the minimum 'Dead Heart' (DH) (10.1 and $11.4 \%$ during the year 2019 and 2020, respectively) was recorded in M3 (clipping of terminal shoots at the time of transplanting and application of cartap hydrochloride $50 \mathrm{SP}$ ) followed by M2 (11.9 and 14.5\% during the year 2019 and 2020, respectively) in which $1^{\text {st }}$ application was done with fipronil 0.3G and $2^{\text {nd }}$ with NSKE 5\% and M1 (19.6 and 20.9\% during the year 2019 and 2020, respectively) i.e. farmers' practice where only carbofuran 3G was applied. 'White Ear Head' (WEH) was also recorded minimum in M3 (11.6 and 12.1\% in the year 2019 and 2020, respectively) followed by M2 (13.3 and 16.4\% in the year 2019 and 2020, respectively) and M1 (20.8 and 22.4\% in the year 2019 and 2020, respectively) in paddy. Maximum yield ( 33.8 and $43.1 \mathrm{q} /$ ha during the year 2019 and 2020, respectively) was also recorded in Module 3 practiced clipping of terminal shoots and spraying with cartap hydrochloride $50 \mathrm{SP}$ with the highest BC(Benefit: Cost) ratio 1.52:1 and 1.94:1 in the year 2019 and 2020, respectively. The overall results of the present study indicating the overall superiority of M3 (clipping of terminal shoots at the time of transplanting and two applications of cartap hydrochloride 50 $\mathrm{SP}$ at 40 and $60 \mathrm{DAT}$ ) in all the aspects i.e. $\mathrm{DH}, \mathrm{WEH}$, yield and $\mathrm{BC}$ ratio.
\end{abstract}

\section{KEYWORDS}

Paddy, Yellow stem borer, Management modules

\begin{tabular}{|c|c|c|}
\hline \multicolumn{3}{|c|}{ ARTICLE INFO } \\
\hline Received on & : & $26 / 02 / 21$ \\
\hline Accepted on & : & $21 / 06 / 21$ \\
\hline Published online & $\cdot$ & $30 / 06 / 21$ \\
\hline
\end{tabular}

\section{INTRODUCTION}

$\mathrm{P}$ addy (Oryza sativa) occupies the prominent place in Indian agriculture (Singh et al, 2017). The production and productivity of paddy is low in Jharkhand and as well as in India as compared to world production (Singh et al, 2009). Amongst various constraints for low productivity of paddy, the infestation of insect pests which attack the crop right from nursery till the harvest of the crop causing about 25 $-30 \%$ of loss (Murlidharan and Pasalu, 2006). Among various insect pests yellow stem borer (YSB), Scirpophaga incertulas (Walker) is quite serious as it can cause $25-30 \%$ damage to the crop, which leads to 'Dead Heart' (DH) in vegetative stage and 'White Ear Head' (WEH) with chaffy grain during heading stage (Rubia et al, 1996). Use of synthetic insecticides is a common method of pest control in paddy among the farmers. But, the indiscriminate use of insecticides have resulted in a number of undesirable side effects such as development of resistant in insects pests, environmental pollution and health hazards to farmers (Holland et al, 2000). Due to these constraints researchers developed an alternative, economical and eco-friendly integrated approach of insect control (Chatterjee et al, 2009). The basic idea of the research problem is to reduce the application of synthetic insecticides and use of cultural, botanical and chemical methods in an integrated approach. In this context present study was planned to assess management modules including botanical, cultural and chemical methods for the management of YSB in paddy.

\section{MATERIALS AND METHODS}

The experiments were carried out during the Kharif season of the year 2019 and 2020 at 10 farmers' field in the village Mahuatand (Sunderpahari block) and Kerabadi (Pauriahaat block) of the district Godda (Jharkhand) by GVT - Krishi Vigyan Kendra, Godda under on farm testing (OFT) activity of the KVK. Three suggested pests management modules including farmers' practices were tested against YSB in paddy (Table 1 ). The trials were laid out in RBD with 03 treatments (modules) in 10 replications during both the years. Twenty five days old seedlings of paddy (Variety: MTU - 7029) were transplanted in $2^{\text {nd }}$ week of August with the spacing $20 \mathrm{~cm} \times 15 \mathrm{~cm}$ in the plot size of $5 \mathrm{~m} \times 4 \mathrm{~m}$. All the other agronomical practices were followed to raise a good and healthy crop as suggested by Choudhary et al (2017) .

\footnotetext{
${ }^{1}$ Gramin Vikas Trust, Krishi Vigyan Kendra, Godda - 814133, Jharkhand, India

"Corresponding author email: sbhushan_bhu23@rediffmail.com
} 
Table 1: Details of pest management modules against yellow stem borer in paddy

\begin{tabular}{ll}
\hline $\begin{array}{l}\text { Pest Management } \\
\text { Modules }\end{array}$ & Details \\
M1 & Farmers' practice (Carbofuran $3 \mathrm{G}, 30 \mathrm{~kg} / \mathrm{ha}, 2-3$ times) \\
M2 & $1^{\text {st }}$ application with Fipronil $0.3 \mathrm{G}(20 \mathrm{~kg} / \mathrm{ha})$ at $40 \mathrm{DAT}^{*}$ followed by $2^{\text {nd }}$ application with NSKE $5 \%$ at $60 \mathrm{DAT}$ \\
M3 & $\begin{array}{l}\text { Clipping of terminal shoots at the time of transplanting and two spraying with cartap hydrochloride } 50 \text { SP (2 } \\
\text { g/litre water) at } 40 \text { and } 60 \text { DAT }\end{array}$ \\
\hline
\end{tabular}

${ }^{*} \mathrm{DAT}=$ days after transplanting

Observations on infestation of yellow stem borer as Dead Heart (DH) and White Ear head (WEH) were recorded on 10 randomly selected hills from three central rows at fortnightly interval after implementation of treatments. The per cent $\mathrm{DH}$ and $\mathrm{WEH}$ were calculated by using the formula given below (Heinrichs et al, 1985):

Per cent Dead Heart $=($ No. of damaged tillers/Total no. of tillers) $\times 100$

Per cent White ear Head $=($ No. of damaged productive tillers/Total no. of productive tillers) $\times 100$

The percent infestation of damage was transformed in to arc sine values for analysis.

The grain yield of each plot was recorded at the time of harvesting and converted in to $\mathrm{q} / \mathrm{ha}$.

The cost incurred on different parameters of agronomic practices viz. nursery management, preparation of land for transplanting, fertilizer application, cost of modules, harvesting etc. were pooled to analyze the cost of cultivation. Based on the current price of inputs used and the produce obtained during both the years, the net return/ha and BC (Benefit Cost) ratio was worked out.

The data collected from the experiments were statistically analyzed according to Gomez and Gomez and Gomez (1984) to test the level of significance of modules.

\section{RESULTS AND DISCUSSION}

The results of the field experiments conducted by GVT Krishi Vigyan Kendra, Godda revealed that all the modules were significantly effective in reducing the infestation of paddy yellow stem borer as compared to the farmers' practice (Table 2 ). The per cent DH was recorded minimum (10.1 and 11.4 during the year 2019 and 2020, respectively) in M3 (clipping of terminal shoots at the time of transplanting and application of cartap hydrochloride 50 SP, 2 g/litre water) followed by M2 (11.9 and 14.5\% during the year 2019 and 2020, respectively) in which $1^{\text {st }}$ application was done with fipronil $0.3 \mathrm{G}$ and $2^{\text {nd }}$ with NSKE 5\% and M1 (19.6 and 20.9\% dur-

The overall results of the present study indicating the overall superiority of M3 (clipping of terminal shoots at the time of transplanting and two applications of cartap hydrochloride $50 \mathrm{SP}$ at 40 and $60 \mathrm{DAT}$ ) in all the aspects i.e. DH, WEH, yield and BC ratio. Pathak (1977) also found clipping of ter- ing the year 2019 and 2020, respectively) i.e. farmers' practice where only carbofuran 3G was applied. WEH was also recorded minimum in M3 (11.6 and 12.1\% in the year 2019 and 2020, respectively) followed by M2 (13.3 and 16.4\% in the year 2019 and 2020, respectively) and M1 (20.8 and 22.4\% in the year 2019 and 2020, respectively).

Table 2: Effect of management modules on the infestation of yellow stem borer in paddy

\begin{tabular}{lllll}
\hline $\begin{array}{l}\text { Pest } \\
\text { Management } \\
\text { Modules }\end{array}$ & \multicolumn{2}{l}{ Dead Heart (DH \%) } & \multicolumn{2}{l}{$\begin{array}{l}\text { White Ear Head (WEH } \\
\%)\end{array}$} \\
& 2019 & 2020 & 2019 & 2020 \\
$\mathrm{M}_{1}$ & 19.6 & 20.9 & 20.8 & 22.4 \\
& $(26.1)$ & $(27.2)$ & $(27.2)$ & $(28.2)$ \\
$\mathrm{M}_{2}$ & 11.9 & 14.5 & 13.3 & 16.4 \\
& $(20.0)$ & $(22.4)$ & $(21.1)$ & $(23.8)$ \\
$\mathrm{M}_{3}$ & 10.1 & 11.4 & 11.6 & 12.1 \\
& $(18.4)$ & $(19.7)$ & $(19.6)$ & $(20.3)$ \\
$\mathrm{CD}(\mathrm{P}=$ & 0.27 & 1.64 & 0.45 & 2.65 \\
$0.05)$ & & & & \\
\hline
\end{tabular}

Values in parentheses are arc sine transformed values

The grain yield data (Table 3 ) also revealed that all the modules were significantly superior over farmers' practice. The grain yield data indicated that M3 recorded the highest yield (33.8 and 43.1 q/ha during the year 2019 and 2020, respectively) followed by M2 (32.6 and $40.5 \mathrm{q} /$ ha during the year 2019 and 2020, respectively) and M1 (30.3 and 36.3 q/ha during the year 2019 and 2020, respectively). Benefit cost ratio was calculated (Table 3 ) and the maximum $\mathrm{BC}$ ratio (1.52:1 and 1.94:1 in the year 2019 and 2020, respectively) was obtained in M3 followed by M2 (1.46:1 and 1.81:1 in the year 2019 and 2020, respectively) and M1 (1.35:1 and 1.61:1 in the year 2019 and 2020, respectively).

minal shoots helpful in reducing the eggs laid at the leaf tips of paddy. The effectiveness of cartap hydrochloride 50 SP against rice pests has been reported by Mishra et al (2012) , Choumule et al (2014), Omprakash et al (2017) and Rajadurai and Kumar (2017) also recorded maximum grain yield of 
Table 3: Economic analysis of pest management modules against yellow stem borer in paddy

\begin{tabular}{|c|c|c|c|c|c|c|c|c|c|}
\hline \multirow{2}{*}{$\begin{array}{l}\text { Pest Man- } \\
\text { agement } \\
\text { Modules }\end{array}$} & \multicolumn{2}{|c|}{ Yield of paddy (q/ha) } & \multirow{2}{*}{$\begin{array}{l}\text { Cost of } \\
\text { cultivation } \\
\text { (Rs./ha) for both } \\
\text { the years }\end{array}$} & \multicolumn{2}{|c|}{$\begin{array}{l}\text { Gross Return (Rs/ha) } \\
\text { (Rs. 1800/q) }\end{array}$} & \multicolumn{2}{|c|}{ Net return (Rs/ha) } & \multicolumn{2}{|c|}{ BC Ratio } \\
\hline & 2019 & 2020 & & 2019 & 2020 & 2019 & 2020 & 2019 & 2020 \\
\hline $\mathrm{M}_{1}$ & 30.3 & 36.3 & 40500 & 54540 & 65340 & 14040 & 24840 & $1.35: 1$ & 1.61:1 \\
\hline $\mathrm{M}_{2}$ & 32.6 & 40.5 & 40300 & 58680 & 72900 & 18380 & 32600 & $1.46: 1$ & 1.81:1 \\
\hline $\mathrm{M}_{3}$ & 33.8 & 43.1 & 40000 & 60840 & 77580 & 20840 & 37580 & $1.52: 1$ & 1.94:1 \\
\hline $\begin{array}{l}\mathrm{CD} \quad(\mathrm{P}= \\
0.05)\end{array}$ & 0.69 & 1.93 & & & & & & & \\
\hline
\end{tabular}

paddy in integrated module.

\section{CONCLUSION}

It has been concluded from the present study that clipping of terminal shoots at the time of transplanting and two spraying with cartap hydrochloride $50 \mathrm{SP}$ (2g/litre water) may be recommended for the management of yellow stem borer in

\section{REFERENCES}

Chatterjee S, Isaia M and Venturino E. 2009. Spiders as biological controllers in the agroecosystem. Journal of Theoretical Biology 258(3):352-362. url: https://dx.doi.org/10.1016/j.jtbi.2008. 11.029. doi: 10.1016/j.jtbi.2008.11.029

Choudhary R, Chandrakar G, Bhardwaj JR, Hh K and Sahu R. 2017. Assessment of the efficacy of neem based pesticides for the management of yellow stem borer, Scirpophaga incertulas (Walker) in paddy field. Journal of Pharmacognosy and Phytochemistry 65(5):1446-1449.

Choumule AJ, Kharbade SB, Sc P and Tamboli ND. 2014. Bio efficacy of new insecticide molecules against rice yellow stem borer. Scirpophaga incertuals (Walker). The Ecoscan 6:63-67.

Gomez KA and Gomez AA 1984. Statistical Procedure for Agricultural Research (New York: John Wiley and Sons).

Heinrichs EA, Fg M and Rapusas H 1985. Genetic evaluation for insect resistance in rice. IRRI (Los Banos, Philippines, Pp) 103279.

Holland JM, Winder L and Perry JN. 2000. The impact of dimethoate on the spatial distribution of beneficial arthropods in winter wheat. Annals of Applied Biology 136(2):93-105. url: https: //dx.doi.org/10.1111/j.1744-7348.2000.tb00013.x. doi: 10.1111/ j.1744-7348.2000.tb00013.x

Mishra MK, Singh RB, J1 D and S A. 2012. Efficacy of insecticides against Scirpophaga incertuals (Walker) in basmati rice. Annals of Plant Protection Sciences 20(2):310-313. paddy.

\section{ACKNOWLEDGEMENTS}

The authors are grateful to the Gramin Vikas Trust (promoted by KRIBHCO) and Director, ICAR - ATARI, Patna for support and encouragement.

Murlidharan K and Pasalu IC. 2006. Assessment of crop losses in rice ecosystem due to stem borer damage. Crop Protection 25(5):409-417.

Omprakash S, Venkataiah M and Laxman S. 2017. Comparative efficacy of some new insecticides against rice yellow stem borer, Scirpophaga incertuals (Walker) under field conditions. Journal of Entomology and Zoology Studies 5(5):1126-1129.

Pathak MD. 1977. The genetic basis of epidermics in agriculture. Ann. N. Y. Acad. Sci 287:287-295.

Rajadurai G and Kumar K. 2017. Field evaluation of different modules against yellow stem borer, Scirpophaga incertuals (Walker) and its effect on natural enemies in rice. Entomon 42(3):247-250.

Rubia EG, Heong KL, Zalucki M, Gonzales B and Norton GA. 1996. Mechanisms of compensation of rice plants to yellow stem borer Scirpophaga incertulas (Walker) injury. Crop Protection 15(4):335-340. url: https://dx.doi.org/10.1016/02612194(95)00102-6. doi: 10.1016/0261-2194(95)00102-6

Singh AK, Singh AK, Kumar R, Prakash V, Sundaram PK and Sk Y. 2017. Indian Cereals Saga: Standpoint and Way Forward. Journal of AgriSearch 4(1):1-10.

Singh AK, Verma VS, Nigam HK, Manibhushan CN and Bharati RC. 2009. Growth, development, yield attribute and yield of upland rice (Oryza sativa) under varying environmental condition and genotypes. Envi. E Ecol 27(2A):880-884.

Citation:

Bhushan S and Shanker R. 2021. Assessment of Management Modules against Yellow Stem Borer in Paddy. Journal of AgriSearch 8(2): 117-119 